\title{
KLASIFIKASI DIAGNOSA PENYAKIT DIABETES MELLITUS (DM) MENGGUNAKAN ALGORITMA C4.4
}

\author{
Abdul Najib, Damar Nurcahyono, Rian Pratma Putra Setiawan \\ Program Studi TIM, Program Studi TI, Program Studi TIM \\ Politeknik Negeri Samarinda \\ Email:abdulnajib@polnes.ac.id, damarnc@polnes.ac.id, rianpratama277@gmail.com
}

\begin{abstract}
Abstrak - Penyakit Diabetes Mellitus (DM) atau kencing manis merupakan salah satu penyakit yang mematikan, diabetes atau kencing manis ini membunuh lebih dari satu juta orang setiap tahunnya dan siapapun dapat terkena, oleh karena itu peneliti mencoba untuk mengklasifikasikan data penyakit diabetes menggunakan algoritma C4.5. Dengan algoritma C4.5 akan menghasilkan decision tree atau pohon keputusan yang mudah dipahami dan mudah dipelajari. Algoritma C4.5 merupakan salah satu algoritma klasifikasi yang ada di dalam data mining. Tujuan dari penelitian ini adalah menerapkan algoritma $\mathrm{C} 4.5$ dalam melakukan diagnosa dan mengetahui persentase error dari data yang sudah ada. Hasil akhir dari perhitungan yaitu prediksi error C4.5 dimana dari 50 data tidak ada data yang error dan menghasilkan akurasi sebesar $100 \%$ artinya akurasi menggunakan algoritma $\mathrm{C} 4.5$ dibilang sangat tinggi.
\end{abstract}

Kata Kunci : Diabetes Mellitus (DM), Data Mining, Klasifikasi, Algoritma C4.5, Decision Tree

\section{PENDAHULUAN}

Kesehatan merupakan hal yang sangat penting bagi setiap makhluk hidup khususnya manusia, untuk mencegah timbulnya masalah kesehatan/penyakit kita harus dapat menjaga makanan yang masuk kedalam tubuh atau mengatur pola makan dan berolahraga secara teratur. Penyakit Diabetes Mellitus (DM) atau kencing manis merupakan salah satu penyakit yang mematikan, diabetes atau kencing manis ini membunuh lebih dari satu juta orang setiap tahunnya dan siapapun dapat terkena. Menurut Organisasi Kesehatan Dunia (WHO) jumlah penderita diabetes terus meningkat dan tercatat saat ini mencapai 422 juta orang di dunia empat kali lebih banyak dari pada 30 tahun lalu.

Teknik klasifikasi data mining dapat membantu untuk menentukan diagnosa penyakit Diabetes Mellitus (DM) atau kencing manis. Keluaran klasifikasi data mining dapat digunakan untuk bahan tambahan edukasi masyarakat tentang bahayanya penyakit Diabetes Mellitus (DM) ini [1].

Algoritma C4.5 dapat membantu dalam mengklasifikasikan diagnosa penyakit diabetes mellitus yang terbagi dalam beberapa atribut. Algoritma C4.5 memiliki kelebihan utama yaitu dapat menghasilkan model berupa tree dan aturan yang mudah diinterpretasikan, memiliki tingkat akurasi yang dapat diterima, dapat menangani atribut bertipe diskrit dan numerik. Pada algoritma C4.5, model yang dihasilkan oleh proses "belajar" dari data pelatihan berupa sebuah decision tree dan rule atau aturan [2].

Banyak metode yang bisa digunakan dalam klasifikasi contoh nya seperti Algoritma C4.5, Algoritma Naïve Bayes, Algoritma Support Vector Machine, Neural Network, dan K-Nearest Neighbour.
Sedangkan metode yang digunakan dalam penelitian ini adalah Algoritma C4.5. Algoritma C4.5 adalah algoritma klasifikasi dan prediksi yang cukup terkenal dan biasanya memiliki akurasi yang tinggi.

Berdasarkan latar belakang diatas, maka penulis bermaksud untuk menerapkan teknik data mining menggunakan metode algoritma $\mathrm{C} 4.5$ dalam bentuk klasifikasi, sehingga dapat membantu untuk mendiagnosa penyakit Diabetes Mellitus (DM).

\section{TINJAUAN PUSTAKA}

\subsection{Data Mining}

Data Mining adalah suatu proses penemuan korelasi, pola dan tren baru yang bermakna dengan menyaring sejumlah besar data yang disimpan dalam repositori, menggunakan teknologi pengenalan pola serta statistik dan teknik matematika [7].

Data Mining merupakan proses yang menggunakan teknik statistik, matematika, kecerdasan buatan dan machine learning untuk mengekstraksi dan mengidentifikasi informasi yang bermanfaat dan pengetahuan yang terkait dari berbagai database besar. Data mining merupakan serangkaian proses untuk menggali nilai tambah dari suatu kumpulan data berupa pengetahuan yang selama ini tidak diketahui secara manual [8].

\subsection{Klasifikasi}

Klasifikasi adalah suatu proses yang menemukan properti-properti yang sama pada sebuah himpunan obyek di dalam sebuah basis data dan mengklasifikasikannya ke dalam kelas-kelas yang berbeda menurut model klasifikasi yang ditetapkan. Tujuan dari klasifikasi adalah untuk menemukan 
model dari training set yang membedakan atribut ke dalam kategori atau kelas yang sesuai, model tersebut kemudian digunakan untuk mengklasifikasikan atribut yang kelasnya belum diketahui sebelumnya [9].

\subsection{Decision Tree}

Pohon keputusan adalah model prediksi menggunakan struktur pohon atau struktur berhirarki. Konsep dari pohon keputusan adalah mengubah data menjadi pohon keputusan dan aturan-aturan keputusan. Data dalam pohon keputusan biasanya dinyatakan dalam bentuk tabel dengan atribut dan record. Atribut menyatakan suatu parameter yang dibuat sebagai kriteria dalam pembentukan tree. Misalkan untuk menentukan main tenis, kriteria yang digunakan adalah cuaca, angin, iklim dan temperatur [10].

Menurut [11] decision tree merupakan salah satu teknik klasifikasi terhadap objek atau record. Teknik ini terdiri dari kumpulan decision node, dan dihubungkan oleh cabang, bergerak ke bawah dari root node sampai berakhir di leaf node.

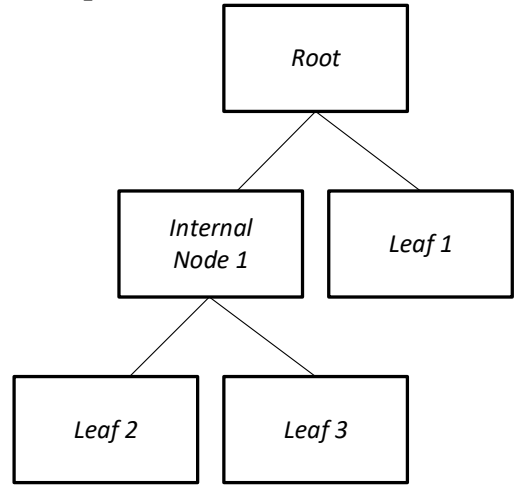

Gambar 2.1 Konsep Pohon Keputusan [11]

Arsitektur pohon keputusan dibuat sedemikian rupa agar menyerupai pohon asli, dimana terdapat beberapa bagian, yaitu [12]:

1. Root Node: Node ini terletak pada bagian paling atas dari pohon keputusan.

2. Internal Node: Node ini merupakan percabangan dimana membutuhkan satu input dan mengeluarkan maksimal dua output.

3. Leaf Node: Node ini merupakan node yang terletak pada ujung pohon. Node ini hanya memiliki satu input dan tidak memiliki output.

Ada beberapa proses yang harus diperhatikan dalam pembentukan struktur pohon, yaitu [13]:

a. Pilih root berdasarkan gain ratio terbesar.

b. Pilih internal root/cabang root berdasar gain ratio terbesar setelah menghapus atribut yang telah terpilih sebagai root.

c. Ulangi sampai semua atribut terhitung nilai gain rationya.

\subsection{Algoritma C4.5}

Algoritma C4.5 merupakan sebuah algoritma yang digunakan untuk membangun decision tree (pohon keputusan). Algoritma $\mathrm{C} 4.5$ dan pohon keputusan merupakan dua model yang tak terpisahkan. Algoritma C4.5 merupakan salah satu algoritma klasifikasi yang kuat dan cukup banyak digunakan atau di implementasikan untuk pengklasifikasian dalam berbagai hal. Algoritma C4.5 diperkenalkan oleh J. Ross Quinlan (1996) sebagai versi perbaikan dari algoritma Iterative Dichotomiser 3 (ID3). Serangkaian perbaikan yang dilakukan pada algoritma ID3 mencapai puncaknya dengan menghasilkan sebuah sistem praktis dan berpengaruh untuk pembentukan pohon keputusan. Perbaikan tersebut meliputi metode untuk menangani data kontinu, mengatasi missing data, dan melakukan pemangkasan pohon [14].

Berikut flowchart dari Algoritma C4.5 untuk membangun sebuah pohon keputusan yang dapat dilihat pada Gambar 2.2.

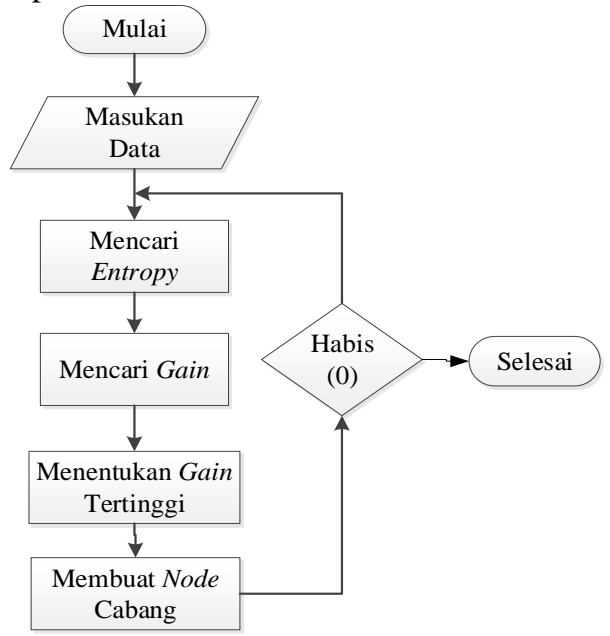

Gambar 2.2 Flowchart Pembangunan Sebuah Pohon Keputusan [4]

Pada Gambar 2.2 memasukan data yang telah ditransformasi ke beberapa atribut, kemudian menghitung nilai entropy dan nilai gain untuk memperoleh gain tertinggi yang akan menjadi atribut akar atau root dari pohon keputusan. Kemudian dilanjutkan kedalam proses pembuatan node cabang untuk masing - masing nilai. Jika setiap kasus dalam cabang tersebut telah berada dalam satu kelas yang sama maka proses perhitungan telah selesai, tapi jika kasus berbeda kelas maka kembali ke perhitungan entropy dan begitu seterusnya hingga semua kasus berada dalam kelas yang sama.

Dalam memilih sebuah atribut menjadi akar, dilakukan perhitungan nilai dari atribut yang ada. Nilai gain yang paling tinggi dijadikan root pada 
pohon keputusan. Untuk menghitung nilai gain digunakan rumus [6], persamaan 2.1

$$
\operatorname{Gain}(S, A)=\operatorname{Entropy}(S)-\sum_{i=1}^{n} \frac{\left|S_{i}\right|}{|S|} * \operatorname{Entropy}(S i)
$$

Keterangan:

S: Himpunan kasus,

A: Atribut,

n: Jumlah partisi dalam atribut,

|Si|: Jumlah kasus pada partisi ke-i,

|S|: Jumlah kasus.

Sedangkan untuk perhitungan nilai entropy dapat dilakukan dengan rumus [6], persamaan 2.2

$$
\operatorname{Entropy}(S)=\sum_{i=1}^{n}-p i * \log _{2} p i
$$

Keterangan:

S: Himpunan kasus, n: Jumlah partisi dalam atribut, pi: Proposi dari Si terhadap S.

Setelah perhitungan selesai, maka dihasilkan pohon keputusan yang dapat diubah menjadi rules menggunakan kaidah IF-THEN-ELSE. Penjelasan rules tersebut adalah sebagai berikut [6]:

\section{a. IF-THEN Rule}

Peraturan induksi: adalah proses penggalian berguna 'jika kemudian' aturan dari data berdasarkan signifikansi statistik. Sebuah sistem Rule berdasarkan membangun satu set if-then-aturan. Pengetahuan merupakan telah pengumpulan bentuk dan strategi penyimpanan dapat dibuat di ini. Untuk analisis, semua data perlu dikonsolidasikan sehingga dapat diobati secara konsisten.

b. IF kondisi THEN Kesimpulan

Aturan ini terdiri dari dua bagian. Aturan yang (bagian $I F$ ) mengandung satu atau lebih kondisi sekitar nilai prediktor atribut mana sebagai akibat aturan (THEN bagian) berisi prediksi tentang nilai atribut tujuan. Prediksi yang akurat dari nilai atribut tujuan akan meningkatkan proses pengambilan keputusan. IF-THEN aturan prediksi sangat populer di data mining. Mereka mewakili menemukan pengetahuan pada tingkat tinggi abstraksi. Aturan Induksi Metode memiliki potensi untuk menggunakan kasus diambil untuk prediksi.

\subsection{Confusion Matrix}

Confussion Matrix adalah proses melakukan pengujian untuk memperkirakan obyek yang benar dan salah. Urutan pengujian ditabulasikan dalam confussion matrix dimana kelas yang di prediksi ditampilkan di bagian atas matriks dan kelas yang diamati di bagian kiri. Setiap sel berisi angka yang menunjukkan berapa banyak kasus yang sebenarnya dari kelas yang diamati untuk diprediksi.

\subsection{Diabetes Mellitus (DM)}

Diabetes Mellitus (DM) atau di Indonesia lebih dikenal dengan istilah kencing manis adalah sebuah penyakit metabolic yang disebabkan oleh kurangnya hormone insulin atau ketidakmampuan tubuh dalam memanfaatkan insulin, sehingga kada glukosa atau kadar gula dalam darah tidak terkendali. Insulin adalah suatu hormone yang dihasilkan oleh kelompok sel beta di pankreas. Insulin memberi sinyal kepada sel tubuh agar menyerap glukosa.

Menurut laporan Riset Kesehatan Dasar (Riskesdas) pada tahun 2007 menunjukkan bahwa prevalensi nasional penyakit DM adalah 1,1\% berdasarkan diagnosis tenaga kesehatan dan gejala. Hasil Riskesdas tahun 2007 itu juga menunjukkan bahwa prevalensi nasional DM (berdasarkan pengukuran gula darah pada penduduk umur diatas 15 tahun di daerah perkotaan) adalah 5,7\%. Sebanyak 13 provinsi di Indonesia mempunyai prevalensi DM diatas prevalensi nasional [15].

\subsection{WEKA}

WEKA adalah sebuah paket toolsmachine learning praktis. "WEKA" merupakan singkatan dari Waikato Environment for Knowledge Analysis, yang dibuat di Universitas Waikato, New Zealand untuk penelitian, pendidikan dan berbagai aplikasi. WEKA mampu menyelesaikan masalah-masalah data mining di dunia nyata, khususnya klasifikasi yang mendasari pendekatan-pendekatan machine learning. Perangkat lunak ini ditulis dalam hirarki class java dengan metode berorientasi objek dan dapat berjalan hampir di semua platform.

WEKA mudah digunakan dan diterapkan pada beberapa tingkatan yang berbeda. Tersedia implementasi algoritma-algoritma pembelajaran stateof-the-art yang dapat diterapkan pada dataset dari command line. WEKA mengandung tools untuk pre-processing data, klasifikasi, regresi, clustering, aturan asosiasi, dan visualisasi. User dapat melakukan preprocess pada data, memasukkannya dalam sebuah skema pembelajaran, dan menganalisa classifier yang dihasilkan dan performansinya, semua itu tanpa menulis kode program sama sekali. Contoh penggunaan WEKA adalah dengan menerapkan sebuah metode pembelajaran ke dataset dan menganalisa hasilnya untuk memperoleh informasi tentang data, atau menerapkan beberapa metode dan membandingkan performansinya untuk dipilih [16]. 


\section{HASIL DAN PEMBAHASAN}

\subsection{Data Penelitian}

Dalam mencari dan mengumpulkan data untuk mendukung penelitian ini, maka data yang diperoleh merupakan data pasien berobat pada salah satu puskesmas yang ada di Kota Samarinda. Data awal yang digunakan dalam perhitungan ini berjumlah 50 data yang terdiri dari jenis kelamin pria sejumlah 26 dan jenis kelamin wanita 24, Berikut ini adalah data yang digunakan yang terdapat pada Tabel 3.1.

\section{Tabel 3.1 Data Awal}

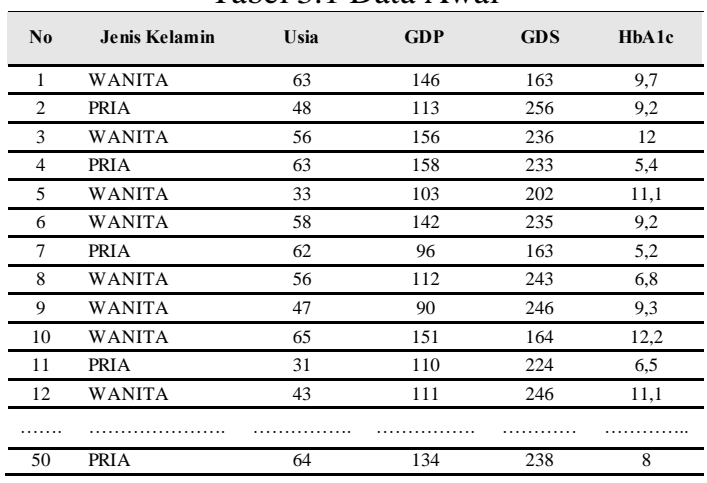

\subsection{Klasifikasi Data}

Agar data pada Tabel 3.1 dapat diolah dengan menggunakan algoritma C4.5, maka data akan ditransformasi. Tranformasi data akan diproses dalam beberapa kelas atau klasifikasi yang telah ditentukan. Data yang di transformasi adalah atribut Usia, GDP (Gula Darah Puasa), GDS (Gula Darah Sewaktu) dan HbA1c. Data yang di proses ke dalam bentuk kelas dapat dilihat pada Tabel 3.2 berikut ini:

Tabel 3.2 Klasifikasi Atribut Diabetes

\begin{tabular}{cl}
\hline \multirow{2}{*}{ Atribut } & \multicolumn{1}{c}{ Kelas } \\
\hline \multirow{2}{*}{ Usia } & \multicolumn{1}{c}{$26-45=$ Dewasa } \\
\cline { 2 - 2 } & $\frac{46-65=\text { Lansia }}{>65=\text { Manula }}$ \\
\hline \multirow{2}{*}{ GDP } & $\frac{80-109=\text { Baik }}{110-125=\text { Sedang }}$ \\
\cline { 2 - 2 } & $\geq 126=$ Buruk \\
\hline \multirow{2}{*}{ GDS } & $<200=$ Baik \\
\cline { 2 - 2 } & $\geq 200=$ Buruk \\
\hline HbA1c & $<6,5=$ Baik \\
\cline { 2 - 2 } & $6,5-8=$ Sedang \\
\hline
\end{tabular}

Klasifikasi atribut pada Tabel 3.2 merupakan acuan yang digunakan dalam pembangunan data untuk perhitungan menggunakan Algoritma C4.5.

Setelah data pada Tabel 3.1 diklasifikasi, maka diperoleh data yang telah terklasifikasikan.
Berikut hasil data setelah diklasifikasi yang terdapat pada Tabel 3.3.

Tabel 3.3 Data Hasil Klasifikasi

\begin{tabular}{|c|c|c|c|c|c|c|}
\hline No & $\begin{array}{c}\text { Jenis } \\
\text { Kelamin }\end{array}$ & Usia & GDP & GDS & HbAlc & Diagnosa \\
\hline 1 & WANITA & LANSIA & BURUK & BURUK & BURUK & POSITIF \\
\hline 2 & $\begin{array}{l}\text { PRIA } \\
\end{array}$ & DEWASA & SEDANG & BURUK & SEDANG & MENUJU POSITIF \\
\hline 3 & WANITA & LANSIA & BURUK & BURUK & BURUK & POSITIF \\
\hline 4 & PRIA & DEWASA & BAIK & BAIK & BAIK & NEGATIF \\
\hline 5 & WANITA & LANSIA & SEDANG & BURUK & BURUK & POSITIF \\
\hline 6 & WANITA & DEWASA & BAIK & BAIK & BAIK & NEGATIF \\
\hline 7 & PRIA & LANSIA & BAIK & BAIK & BAIK & NEGATIF \\
\hline 8 & WANITA & MANULA & SEDANG & BURUK & SEDANG & MENUJU POSITIF \\
\hline 9 & WANITA & LANSIA & SEDANG & BURUK & SEDANG & MENUJU POSITIF \\
\hline 10 & WANITA & DEWASA & BURUK & BURUK & BURUK & POSITIF \\
\hline 11 & PRIA & MANULA & BURUK & BURUK & BURUK & POSITIF \\
\hline 12 & WANITA & MANULA & SEDANG & BURUK & SEDANG & MENUJU POSITIF \\
\hline$\ldots$ & . ……......... & ……......... & . …....... & & ……... & $\ldots \ldots \ldots \ldots$. \\
\hline 50 & PRIA & LANSIA & SEDANG & SEDANG & BURUK & MENUJU POSITIF \\
\hline
\end{tabular}

Dapat dilihat pada tabel diatas bahwa data telah terklasifikasikan sesuai kelas klasifikasi yang dapat dilihat pada tabel 3.2.

\subsection{Perhitungan Algortima C4.5}

Setelah data ditransformasi dengan mengklasifikasikan ke dalam beberapa kelas, maka data pada Tabel 3.3 dapat dilakukan perhitungan menggunakan algoritma $\mathrm{C} 4.5$ untuk membuat decision tree atau pohon keputusan dan rule/aturan. Decision tree atau pohon keputusan dibuat untuk mengetahui algoritma $\mathrm{C} 4.5$ dalam mendiagnosa penyakit Diabetes Mellitus (DM) serta rule/aturan untuk mengetahui prediksi error menurut algoritma C4.5. Berikut adalah langkah-langkah dalam mendiagnosa penyakit diabetes menggunakan algoritma $\mathrm{C} 4.5$

1. Mencari node $1 /$ root node dengan meghitung nilai entropy, nilai gain, dan memilih gain tertinggi sebagai dasar decision tree,

2. Membuat node cabang,

3. Membuat rule/aturan dari decision tree.

4. Menghitung nilai error menurut decision tree

\subsection{Mencari Root Node}

Tahap pertama adalah mencari root node dengan menghitung jumlah data, menghitung entropy dan gain pada masing-masing atribut menggunakan rumus persamaan 2.1 untuk menghitung gain dan persamaan 2.2 untuk menghitung entropy selanjutnya memilih gain tertinggi sebagai dasar decision tree. 
Najib, dkk. Klasifikasi Diagnosa Penyakit Diabetes Mellitus (DM) Menggunakan Algoritma C4.4

Tabel 3.4 Perhitungan Root Node

\begin{tabular}{llcccccc}
\hline Atribut & Value & $\begin{array}{c}\text { Jumlah } \\
\text { Kasus } \\
(\mathrm{S})\end{array}$ & $\begin{array}{c}\text { Positif } \\
(\mathrm{S} 1)\end{array}$ & $\begin{array}{c}\text { Menuju } \\
\text { Positif } \\
(\mathrm{S} 2)\end{array}$ & $\begin{array}{c}\text { Negatif } \\
\text { (S3) }\end{array}$ & Entropy & Gain \\
\hline Total & & 50 & 22 & 17 & 11 & 1,5309 & \\
\hline Jenis Kelamin & & & & & & & 1,9310 \\
\hline & Pria & 19 & 10 & 5 & 4 & 1,4675 & \\
\hline & Wanita & 31 & 12 & 12 & 7 & 1,5448 & \\
\hline Usia & & & & & & & 1,8611 \\
\hline & Dewasa & 17 & 7 & 3 & 7 & 1,4958 & \\
\hline & Lansia & 16 & 6 & 6 & 4 & 1,5613 & \\
\hline & Manula & 17 & 9 & 8 & 0 & 0,9975 & \\
\hline GDP & & & & & & & 1,7324 \\
\hline & Baik & 13 & 0 & 2 & 11 & 0,6194 & \\
\hline & Sedang & 21 & 6 & 15 & 0 & 0,8631 & \\
\hline & Buruk & 16 & 16 & 0 & 0 & 0 & \\
\hline GDS & & & & & & & 2,3016 \\
\hline & Baik & 11 & 0 & 0 & 11 & 0 & \\
\hline & Buruk & 39 & 22 & 17 & 0 & 0,9881 & \\
\hline HbA1c & & & & & & & 1,6944 \\
\hline & Baik & 13 & 0 & 2 & 11 & 0,6194 & \\
\hline & Sedang & 20 & 5 & 15 & 0 & 0,8113 & \\
\hline & Buruk & 17 & 17 & 0 & 0 & 0 & \\
\hline
\end{tabular}

Berdasarkan hasil perhitungan table diatas, dapat diketahui bahwa nilai gain terbesar adalah atribut "GDS" yaitu sebesar 2,3016. Sehingga atribut "GDS" menjadi root node dan terdapat 2 nilai atribut, yaitu Baik dan Buruk yang terlihat pada Gambar 3.1 berikut ini:

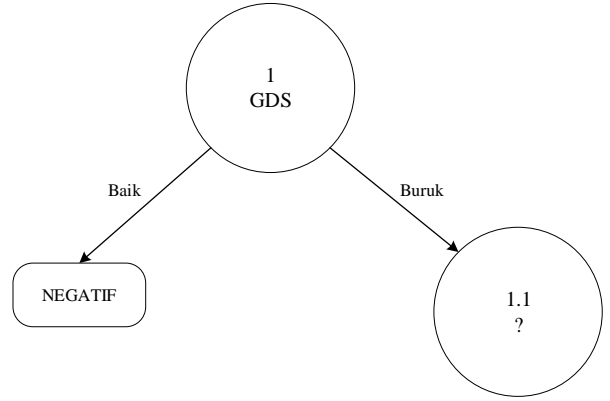

Gambar 3.1 Pohon Keputusan Root Node

Seperti terlihat pada Gambar 3.1 yang terbentuk dari hasil perhitungan sesuai dengan Tabel 3.4, maka didapatkan atribut "GDS" sebagai root node. Untuk "GDS = Baik" sudah memiliki label yaitu "Negatif" maka artinya untuk "GDS = Baik" sudah memiliki kelas yang sama dan tidak perlu dihitung kembali karena sudah memiliki label. untuk "GDS = Buruk" masih tanda tanya artinya pada atribut "GDS = Buruk" masih memiliki nilai atau masih ragu-ragu dalam mendiagnosa apakah dikatakan "Positif", "Menuju Positif' atau "Negatif" maka diperlukan perhitungan ulang untuk "Usia = Baik" dan "GDS = Buruk" dan akan menjadi node selanjutnya.

\subsection{Mencari Node 1.1}

Untuk menentukan node 1.1 dilakukan perhitungan ulang dengan filter data untuk "GDS = Buruk" dan dapat dilakukan dengan menghitung atribut lain yang memiliki atribut "GDS = Buruk".
Tabel 3.5 Mencari Node 1.1

\begin{tabular}{|c|c|c|c|c|c|c|c|}
\hline Atribut & Value & $\begin{array}{c}\text { Jumlah } \\
\text { Kasus } \\
\text { (S) }\end{array}$ & $\begin{array}{l}\text { Positif } \\
\text { (S1) }\end{array}$ & $\begin{array}{c}\text { Menuju } \\
\text { Positif } \\
\text { (S2) }\end{array}$ & $\begin{array}{c}\text { Negatif } \\
\text { (S3) }\end{array}$ & Entropy & Gain \\
\hline GDS $=$ Buruk & & 39 & 22 & 17 & 0 & 0,9881 & \\
\hline \multirow[t]{3}{*}{ Jenis Kelamin } & & & & & & & 1,2503 \\
\hline & Pria & 15 & 10 & 5 & 0 & 0,9183 & \\
\hline & Wanita & 24 & 12 & 12 & 0 & 1,0000 & \\
\hline \multirow[t]{4}{*}{ Usia } & & & & & & & 1,5046 \\
\hline & Dewasa & 10 & 7 & 3 & 0 & 0,8813 & \\
\hline & Lansia & 12 & 6 & 6 & 0 & 1,0000 & \\
\hline & Manula & 17 & 9 & 8 & 0 & 0,9975 & \\
\hline \multirow[t]{4}{*}{ GDP } & & & & & & & 1,4529 \\
\hline & Baik & 2 & 0 & 2 & 0 & 0 & \\
\hline & Sedang & 21 & 6 & 15 & 0 & 0,8631 & \\
\hline & Buruk & 16 & 16 & 0 & 0 & 0 & \\
\hline \multirow[t]{4}{*}{$\mathrm{HbAlc}$} & & & & & & & 1,4042 \\
\hline & Baik & 2 & 0 & 2 & 0 & 0 & \\
\hline & Sedang & 20 & 5 & 15 & 0 & 0,8113 & \\
\hline & Buruk & 17 & 17 & 0 & 0 & 0 & \\
\hline
\end{tabular}

Berdasarkan perhitungan pada tabel 3.5, dapat diketahui bahwa nilai gain terbesar adalah atribut "Usia" yaitu sebesar 1,5046. Sehingga atribut "Usia" menjadi node selanjutnya yaitu node 1.1.

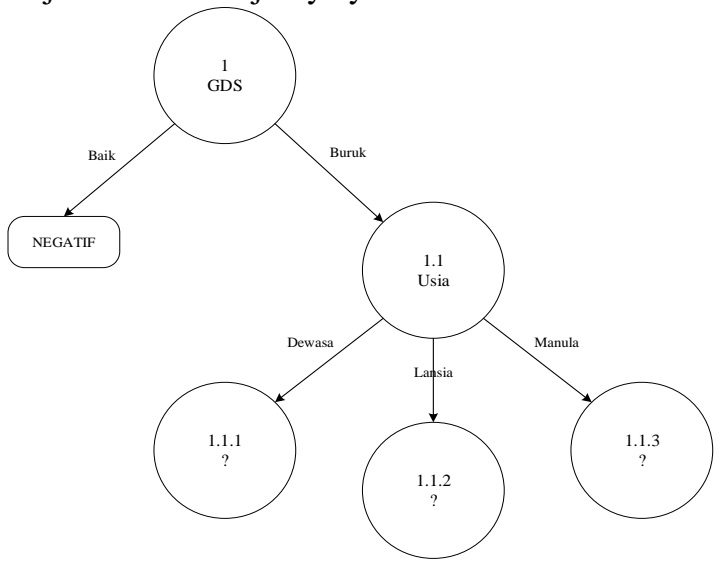

Gambar 3.2 Pohon Keputusan Node 1.1

Berdasarkan pada pohon keputusan Gambar 3.2 yang terbentuk dari hasil perhitungan sesuai dengan Tabel 3.5, maka didapatkan atribut "Usia" sebagai node 1.1 dan untuk node selanjutnya semua masih tanda tanya artinya pada atribut "Usia = Dewasa", "Usia = Lansia", dan "Usia = Manula" masih memiliki nilai atau masih ragu-ragu dalam mendiagnosa apakah dikatakan "Positif", "Menuju Positif' atau "Negatif" maka diperlukan perhitungan ulang untuk "GDS = Buruk dan Usia = Dewasa", "GDS = Buruk dan Usia = Lansia" dan "GDS = Buruk dan Usia = Manula" dan akan menjadi node selanjutnya.

\subsection{Mencari Node 1.1.1}

Untuk mencari node 1.1.1 dilakukan perhitungan ulang untuk "GDS = Buruk" dan "Usia = Dewasa" dan dapat dilihat pada Tabel 3.6. 
Tabel 3.6 Mencari Node 1.1.1

\begin{tabular}{llllllll}
\hline Atribut & Value & $\begin{array}{c}\text { Jumlah } \\
\text { Kasus } \\
(\mathrm{S})\end{array}$ & $\begin{array}{c}\text { Positif } \\
\text { (S1) }\end{array}$ & $\begin{array}{c}\text { Menuju } \\
\text { Positif } \\
\text { (S2) }\end{array}$ & $\begin{array}{c}\text { Negatif } \\
\text { (S3) }\end{array}$ & Entropy & Gain \\
\hline $\begin{array}{c}\text { GDS = Buruk AND } \\
\text { Usia = Dewasa }\end{array}$ & 10 & 7 & 3 & 0 & 0,8813 & \\
\hline Jenis Kelamin & & & & & & & 0,2813 \\
\hline & Pria & 6 & 3 & 3 & 0 & 1,0000 & \\
\hline & Wanita & 4 & 4 & 0 & 0 & 0 & \\
\hline GDP & & & & & & & 1,3668 \\
\hline & Baik & 0 & 0 & 0 & 0 & 0 & \\
\hline & Sedang & 5 & 3 & 2 & 0 & 0,9710 & \\
\hline Buruk & 5 & 5 & 0 & 0 & 0 & \\
\hline HbAlc & & & & & & & 1,3668 \\
\hline & Baik & 1 & 0 & 1 & 0 & 0 & \\
\hline & Sedang & 5 & 3 & 2 & 0 & 0,9710 & \\
\hline Buruk & 4 & 4 & 0 & 0 & 0 & \\
\hline
\end{tabular}

Berdasarkan pada tabel 3.6, dapat diketahui bahwa nilai gain terbesar adalah atribut "GDP" yaitu sebesar 1,3668. Sehingga atribut "GDP" menjadi node selanjutnya yaitu node 1.1.1. Dapat dilihat dari Tabel 3.6 perhitungan node 1.1.2 bahwa atribut "GDP" terdapat 3 nilai atribut, yaitu Baik, Sedang dan Buruk yang dapat dilihat pada Gambar 3.3

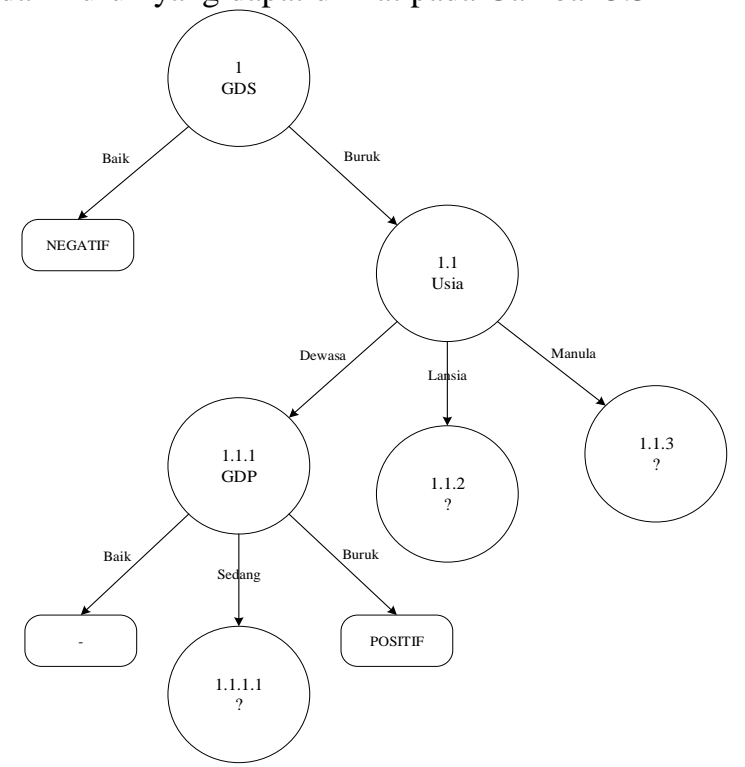

Gambar 3.5 Pohon Keputusan Node 1.1.1

Berdasarkan pada Gambar 3.5 yang terbentuk dari hasil perhitungan sesuai dengan Tabel 4.6, maka didapatkan atribut "GDP" sebagai node 1.1.1. Dapat dilihat bahwa untuk nilai atribut "GDP = Baik" telah memiliki label yaitu "-” atau tidak ada data yang ditunjukkan pada kondisi tersebut dan untuk nilai atribut "GDP = Buruk" juga telah memiliki label yaitu "Positif" sedangkan untuk nilai atribut "GDP = Sedang" masih tanda tanya artinya masih memiliki nilai atau masih ragu-ragu dalam mendiagnosa apakah dikatakan "Positif", "Menuju Positif" atau "Negatif" maka diperlukan perhitungan ulang untuk "GDS = Buruk", "Usia = Dewasa", dan "GDP = Sedang" dan akan menjadi node selanjutnya yaitu node 1.1.1.1.

\subsection{Mencari Node 1.1.1.1}

Untuk mencari node 1.1.1.1 dilakukan perhitungan ulang dengan "GDS = Buruk", "Usia = Dewasa", dan "GDP = Sedang”. Untuk mencari node 1.1.1.1 dapat dilakukan dengan menghitung atribut lain yang memiliki atribut "GDS = Buruk", "Usia = Dewasa", dan "GDP = Sedang".

Tabel 3.7 Mencari Node 1.1.1.1

\begin{tabular}{lccccccc}
\hline Atribut & Value & $\begin{array}{c}\text { Jumlah } \\
\text { Kasus } \\
\text { (S) }\end{array}$ & $\begin{array}{c}\text { Positif } \\
\text { (S1) }\end{array}$ & $\begin{array}{c}\text { Menuju } \\
\text { Positif } \\
\text { (S2) }\end{array}$ & $\begin{array}{c}\text { Negatif } \\
\text { (S3) }\end{array}$ & Entropy & Gain \\
\hline $\begin{array}{c}\text { GDS = Buruk AND } \\
\text { Usia = Dewasa AND } \\
\text { GDP = Sedang }\end{array}$ & & 5 & 2 & 3 & 0 & 0,9710 & \\
\hline Jenis Kelamin & & & & & & & 0,3219 \\
\hline & Pria & 4 & 1 & 3 & 0 & 0,8113 & \\
\hline Wanita & 1 & 1 & 0 & 0 & 0 & \\
\hline HbAlc & & & & & & & 0,9710 \\
\hline & Baik & 1 & 0 & 1 & 0 & 0 & \\
\hline & Sedang & 2 & 0 & 2 & 0 & 0 & \\
\hline Buruk & 2 & 2 & 0 & 0 & 0 & \\
\hline
\end{tabular}

Berdasarkan pada tabel 3.7, dapat diketahui bahwa nilai gain terbesar adalah atribut "HbA1c" yaitu sebesar 0,9710. Sehingga atribut "HbA1c" menjadi node selanjutnya yaitu node 1.1.1.1. Dapat dilihat dari Tabel 3.7 perhitungan node 1.1.1.1 bahwa atribut "HbA1c" terdapat 3 nilai atribut, yaitu Baik, Sedang dan Buruk.

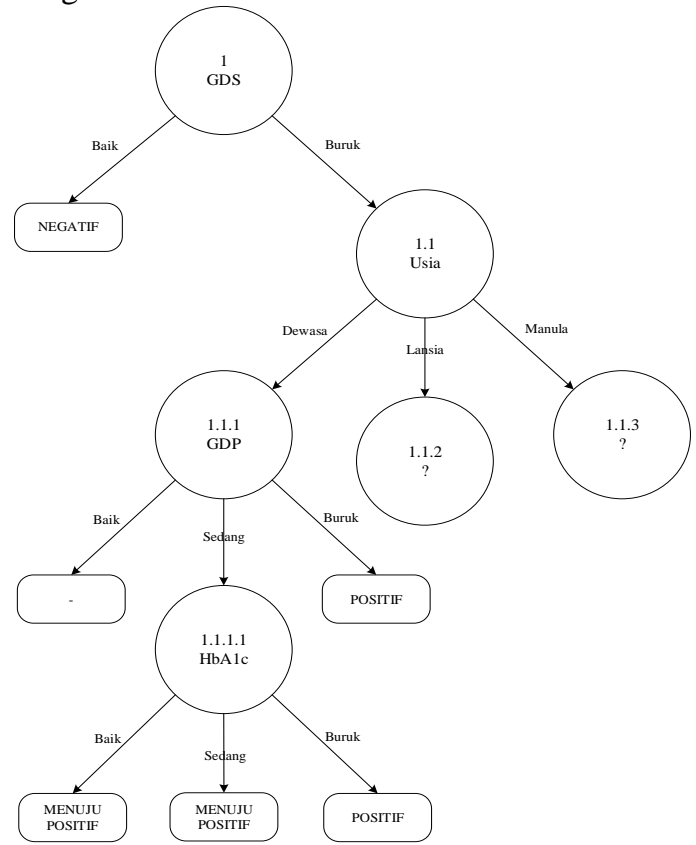

Gambar 3.6 Pohon Keputusan Node 1.1.1.1

Berdasarkan pada Gambar 3.6 yang terbentuk dari hasil perhitungan sesuai dengan Tabel 3.7, maka didapatkan atribut "HbA1c" sebagai node 1.1.1.1. Pada Gambar 3.6 menyatakan bahwa semua value pada atribut "HbA1c" sudah memiliki label atau telah diketahui kelas nya untuk "HbA1c = Baik" memiliki kelas "Menuju Positif", "HbA1c = Sedang" memiliki kelas "Menuju Positif" dan untuk "HbA1c = Buruk" memiliki kelas "Positif". 


\subsection{Mencari Node 1.1.2}

Untuk menentukan node 1.1.2 dilakukan perhitungan ulang dengan filter data untuk "GDS = Buruk" dan "Usia = Lansia". Untuk mencari node 1.1.2 dapat dilakukan dengan menghitung atribut lain yang memiliki atribut "GDS=Buruk" dan "Usia= Lansia".

Tabel 3.8 Mencari Node 1.1.2

\begin{tabular}{cccccccc}
\hline \multicolumn{1}{c}{ Atribut } & Value & $\begin{array}{c}\text { Jumlah } \\
\text { Kasus } \\
\text { (S) }\end{array}$ & $\begin{array}{c}\text { Positif } \\
\text { (S1) }\end{array}$ & $\begin{array}{c}\text { Menuju } \\
\text { Positif } \\
\text { (S2) }\end{array}$ & $\begin{array}{c}\text { Negatif } \\
\text { (S3) }\end{array}$ & Entropy & Gain \\
\hline $\begin{array}{l}\text { GDS = Buruk AND } \\
\text { Usia = Lansia }\end{array}$ & & 12 & 6 & 6 & 0 & 1,0000 & \\
\hline Jenis Kelamin & & & & & & & 1,3333 \\
\hline & Pria & 4 & 2 & 2 & 0 & 1,0000 & \\
\hline & Wanita & 8 & 4 & 4 & 0 & 1,0000 & \\
\hline GDP & & & & & & & 1,3250 \\
\hline & Baik & 1 & 0 & 1 & 0 & 0 & \\
\hline & Sedang & 6 & 1 & 5 & 0 & 0,6500 & \\
\hline Buruk & 5 & 5 & 0 & 0 & 0 & \\
\hline HbA1c & & & & & & & 1,3250 \\
\hline & Baik & 1 & 0 & 1 & 0 & 0 & \\
\hline & Sedang & 6 & 1 & 5 & 0 & 0,6500 & \\
\hline Buruk & 5 & 5 & 0 & 0 & 0 & \\
\hline
\end{tabular}

Berdasarkan perhitungan pada tabel 3.8, dapat diketahui bahwa nilai gain terbesar adalah atribut "Jenis Kelamin" yaitu sebesar 1,3333. Sehingga atribut "Jenis Kelamin" menjadi node selanjutnya yaitu node 1.1.2 dan terdapat 2 nilai atribut, yaitu Pria dan Wanita.

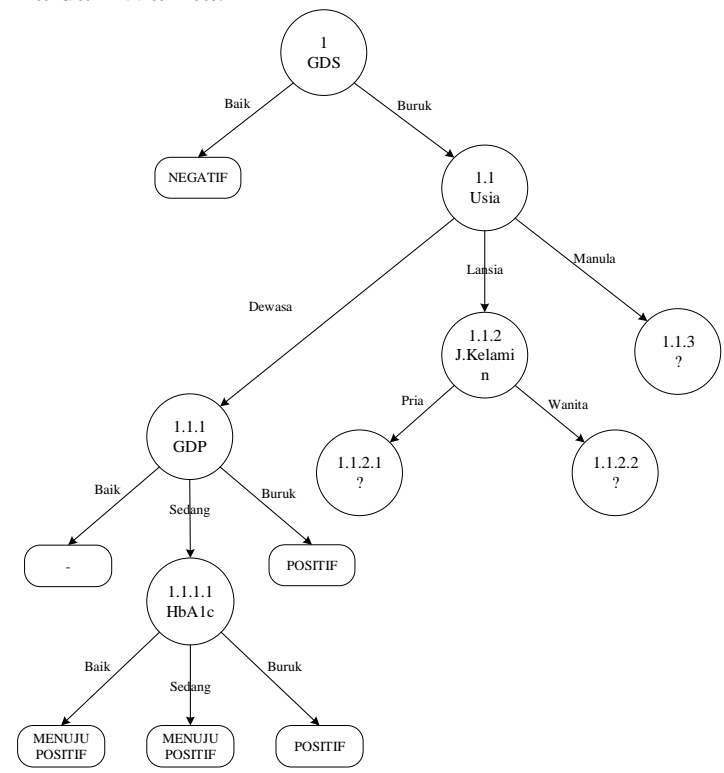

Gambar 3.7 Pohon Keputusan Node 1.1.2

Berdasarkan pada Gambar 3.7 yang terbentuk dari hasil perhitungan sesuai dengan Tabel 3.8, maka didapatkan atribut "Jenis Kelamin" sebagai node 1.1.2. Dapat dilihat bahwa untuk kedua nilai atribut "Jenis Kelamin" masih tanda tanya artinya masih memiliki nilai atau masih ragu-ragu dalam mendiagnosa apakah dikatakan "Positif", "Menuju Positif" atau "Negatif" maka diperlukan perhitungan ulang untuk "GDS=Buruk", "Usia=Lansia", "Jenis Kelamin=Pria" dan akan menjadi node selanjutnya.

\subsection{Mencari Node 1.1.2.1}

Untuk menentukan node 1.1.2.1 dilakukan perhitungan ulang dengan filter data untuk "GDS = Buruk", "Usia = Lansia" dan "Jenis Kelamin = Pria". Untuk mencari node 1.1.2.1 dapat dilakukan dengan menghitung atribut lain yang memiliki atribut "GDS =Buruk", "Usia=Lansia" dan "Jenis Kelamin=Pria".

Tabel 3.9 Mencari Node 1.1.2.1

\begin{tabular}{llllllll}
\hline Atribut & Value & $\begin{array}{c}\text { Jumlah } \\
\text { Kasus } \\
\text { (S) }\end{array}$ & $\begin{array}{c}\text { Positif } \\
\text { (S1) }\end{array}$ & $\begin{array}{c}\text { Menuju } \\
\text { Positif } \\
\text { (S2) }\end{array}$ & $\begin{array}{c}\text { Negatif } \\
\text { (S3) }\end{array}$ & Entropy & Gain \\
\hline $\begin{array}{c}\text { GDS = Buruk AND } \\
\begin{array}{c}\text { Usia = Lansia AND } \\
\text { J.Kelamin = Pria }\end{array}\end{array}$ & 4 & 2 & 2 & 0 & 1,0000 & \\
\hline GDP & & & & & & & 1,0000 \\
\hline & Baik & 0 & 0 & 0 & 0 & 0 & \\
\hline & Sedang & 2 & 0 & 2 & 0 & 0 & \\
\hline Buruk & 2 & 2 & 0 & 0 & 0 & \\
\hline HbAlc & & & & & & & 1,6887 \\
\hline & Baik & 0 & 0 & 0 & 0 & 0 & \\
\hline & Sedang & 3 & 1 & 2 & 0 & 0,9183 & \\
\hline Buruk & 1 & 1 & 0 & 0 & 0 & \\
\hline
\end{tabular}

Berdasarkan perhitungan pada tabel 3.9, dapat diketahui bahwa nilai gain terbesar adalah atribut "HbA1c" yaitu sebesar 1,6887. Sehingga atribut "HbA1c" menjadi node selanjutnya yaitu node 1.1.2.1 dan terdapat 3 nilai atribut, yaitu Baik, Sedang dan Buruk.

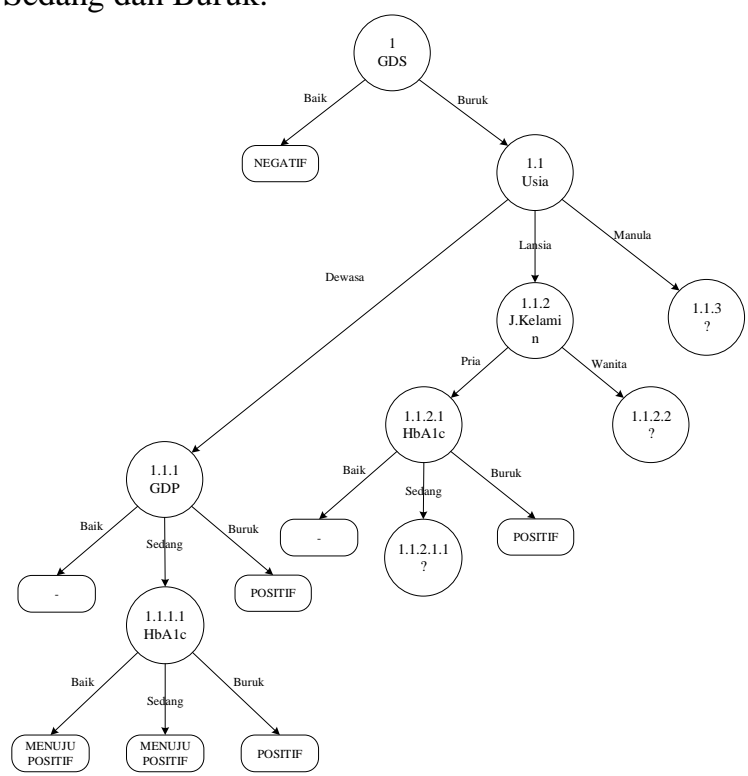

Gambar 3.8 Pohon Keputusan Node 1.1.2.1

Berdasakan pada Gambar 3.8 yang terbentuk dari hasil perhitungan sesuai dengan Tabel 3.9, maka didapatkan atribut "HbA1c" sebagai node 1.1.2.1. Dapat dilihat bahwa untuk nilai atribut "HbA1c = Baik" telah memiliki label yaitu "_" atau tidak ada data yang ditunjukkan pada kondisi tersebut dan untuk nilai atribut "HbA1c=Buruk" juga telah memiliki label yaitu "Positif" sedangkan untuk nilai atribut "HbA1c=Sedang" masih tanda tanya artinya masih memiliki nilai atau masih ragu-ragu dalam mendiagnosa apakah dikatakan "Positif", "Menuju Positif" atau "Negatif" maka diperlukan perhitungan ulang untuk "GDS=Buruk", "Usia=Lansia", "Jenis 
Kelamin=Pria" dan "HbA1c=Sedang" yang akan menjadi node selanjutnya yaitu node 1.1.2.1.1.

\subsection{Mencari Node 1.1.2.1.1}

Untuk menentukan node 1.1.2.1.1 dilakukan perhitungan ulang dengan filter data dan menghitung atribut lain yang memiliki "GDS = Buruk", "Usia=Lansia", "Jenis Kelamin=Pria" dan "HbA1c= Sedang".

\begin{tabular}{|c|c|c|c|c|c|c|c|}
\hline Atribut & Value & $\begin{array}{c}\text { Jumlah } \\
\text { Kasus } \\
\text { (S) }\end{array}$ & $\begin{array}{l}\text { Positif } \\
\text { (S1) }\end{array}$ & $\begin{array}{c}\text { Menuju } \\
\text { Positif } \\
\text { (S2) }\end{array}$ & $\begin{array}{l}\text { Negatif } \\
\text { (S3) }\end{array}$ & Entropy & Gain \\
\hline $\begin{array}{c}\text { GDS = Buruk AND } \\
\text { Usia }=\text { Lansia AND } \\
\text { J.Kelamin = Pria } \\
\text { AND HbA1c = } \\
\text { Sedang }\end{array}$ & & 3 & 1 & 2 & 0 & 0,9183 & \\
\hline GDP & & & & & & & 0,9183 \\
\hline & Baik & 0 & 0 & 0 & 0 & 0 & \\
\hline & Sedang & 2 & 0 & 2 & 0 & 0 & \\
\hline & Buruk & 1 & 1 & 0 & 0 & 0 & \\
\hline
\end{tabular}

Berdasarkan perhitungan pada tabel 3.10, dapat diketahui bahwa nilai gain terbesar adalah atribut "GDP" yaitu sebesar 0,9183. Sehingga atribut "GDP" menjadi node selanjutnya yaitu node 1.1.2.1.1. dan terdapat 3 nilai atribut, yaitu Baik, Sedang dan Buruk.

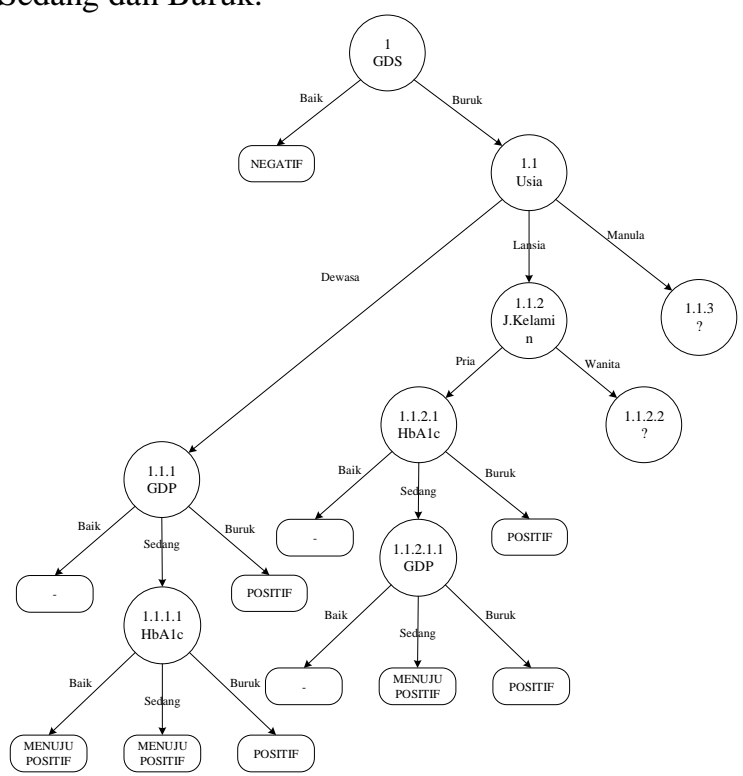

Gambar 3.9 Pohon Keputusan Node 1.1.2.1.1

Berdasarkan pada Gambar 4.9 yang terbentuk dari hasil perhitungan sesuai dengan Tabel 3.10, maka didapatkan atribut "GDP" sebagai node 1.1.2.1. Dapat dilihat pada Gambar 3.7 bahwa semua nilai pada atribut "GDP" sudah memiliki label atau telah diketahui kelas nya untuk "GDP=Baik" memiliki kelas "-" yang artinya tidak ada data yang dapat ditampilkan pada kondisi tersebut, "GDP=Sedang" memiliki kelas "Menuju Positif" dan untuk "GDP= Buruk" memiliki kelas "Positif".

\subsection{Mencari Node 1.1.2.2}

Untuk menentukan node 1.1.2.2 dilakukan perhitungan ulang dengan menyaring data dan menghitung atribut lain yang memiliki "GDS = Buruk", "Usia = Lansia" dan "Jenis Kelamin = Wanita".

\begin{tabular}{|c|c|c|c|c|c|c|c|}
\hline Atribut & Value & $\begin{array}{c}\text { Jumlah } \\
\text { Kasus } \\
\text { (S) }\end{array}$ & $\begin{array}{l}\text { Positif } \\
\text { (S1) }\end{array}$ & $\begin{array}{c}\text { Menuju } \\
\text { Positif } \\
\text { (S2) }\end{array}$ & $\begin{array}{l}\text { Negatif } \\
\text { (S3) }\end{array}$ & Entropy & Gain \\
\hline $\begin{array}{c}\text { GDS = Buruk } \\
\text { AND Usia = } \\
\text { Lansia AND } \\
\text { J.Kelamin = } \\
\text { Wanita }\end{array}$ & & 8 & 4 & 4 & 0 & 1,0000 & \\
\hline GDP & & & & & & & 1,4056 \\
\hline & Baik & 1 & 0 & 1 & 0 & 0 & \\
\hline & Sedang & 4 & 1 & 3 & 0 & 0,8113 & \\
\hline & Buruk & 3 & 3 & 0 & 0 & 0 & \\
\hline HbA1c & & & & & & & 1,0000 \\
\hline & Baik & 1 & 0 & 1 & 0 & 0 & \\
\hline & Sedang & 3 & 0 & 3 & 0 & 0,0000 & \\
\hline & Buruk & 4 & 4 & 0 & 0 & 0 & \\
\hline
\end{tabular}

Berdasarkan perhitungan pada Tabel 3.11, dapat diketahui bahwa nilai gain terbesar adalah atribut "GDP" yaitu sebesar 1,4056. Sehingga atribut "GDP" menjadi node selanjutnya yaitu node 1.1.2.2. Dapat dilihat dari Tabel 3.11 perhitungan node 1.1.2.2 bahwa atribut "GDP" terdapat 3 nilai atribut, yaitu Baik, Sedang dan Buruk.

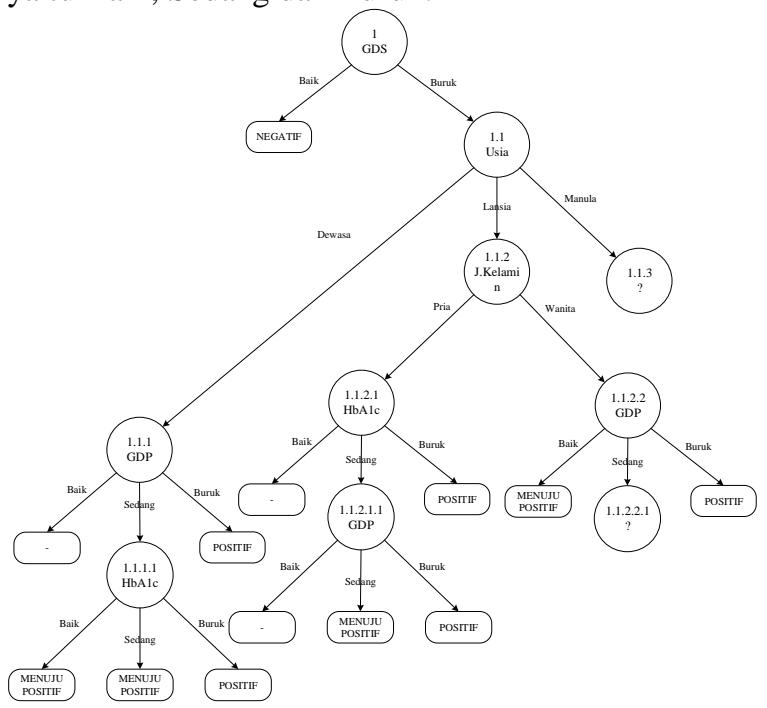

Gambar 3.10 Pohon Keputusan Node 1.1.2.2

Berdasarkan pada Gambar 3.8 yang terbentuk dari hasil perhitungan sesuai dengan Tabel 3.11, maka didapatkan atribut "GDP" sebagai node 1.1.2.2. Dapat dilihat bahwa untuk nilai atribut "GDP = Baik" telah memiliki label yaitu "-" atau tidak ada data yang ditunjukkan pada kondisi tersebut dan untuk nilai atribut "GDP = Buruk" juga telah memiliki label yaitu "Positif" sedangkan untuk nilai atribut "HbA1c = Sedang" masih tanda tanya artinya masih memiliki nilai atau masih ragu-ragu dalam mendiagnosa apakah dikatakan "Positif", "Menuju Positif" atau "Negatif" maka diperlukan perhitungan ulang untuk "GDS = Buruk", "Usia = Lansia", "Jenis Kelamin = 
Wanita" dan "GDP = Sedang" yang akan menjadi node selanjutnya yaitu node 1.1.2.2.1.

\subsection{Mencari Node 1.1.2.2.1}

Untuk menentukan node 1.1.2.2.1 dilakukan perhitungan ulang dengan menyaring data dan menghitung atribut lain yang memiliki "GDS = Buruk", "Usia = Lansia", "Jenis Kelamin = Wanita" dan "GDP = Sedang".

Tabel 3.12 Mencari Node 1.1.2.2.1

\begin{tabular}{|c|c|c|c|c|c|c|c|}
\hline Atribut & Value & $\begin{array}{c}\text { Jumlah } \\
\text { Kasus } \\
\text { (S) }\end{array}$ & 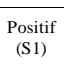 & $\begin{array}{l}\text { Menuju } \\
\text { Positif } \\
\text { (S2) }\end{array}$ & $\begin{array}{c}\text { Negatif } \\
\text { (S3) }\end{array}$ & Entropy & Gain \\
\hline $\begin{array}{l}\text { GDS = Buruk AND } \\
\text { Usia }=\text { Lansia AND } \\
\text { J.Kelamin = Wanita } \\
\text { AND GDP = Sedang }\end{array}$ & & 4 & 1 & 3 & 0 & 0,8113 & \\
\hline HbAlc & & & & & & & 0,8113 \\
\hline & Baik & 1 & 0 & 1 & 0 & 0 & \\
\hline & Sedang & 2 & 0 & 2 & 0 & 0 & \\
\hline & Buruk & 1 & 1 & 0 & 0 & 0 & \\
\hline
\end{tabular}

Berdasarkan perhitungan pada Tabel 3.12, dapat diketahui bahwa nilai gain terbesar adalah atribut "HbA1c" yaitu sebesar 0,8113. Sehingga atribut "HbA1c" menjadi node selanjutnya yaitu node 1.1.2.2.1 dan terdapat 3 nilai atribut, yaitu Baik, Sedang dan Buruk.

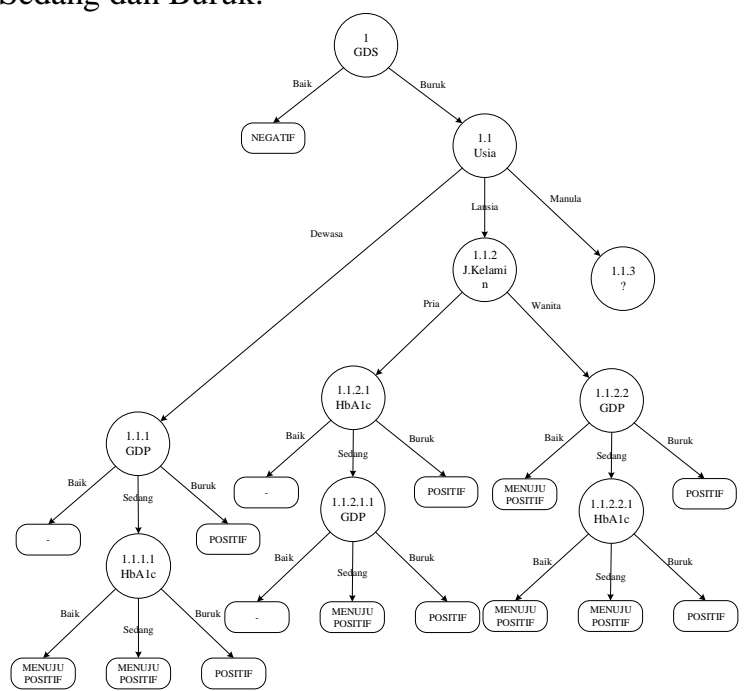

Gambar 3.11 Pohon Keputusan Node 1.1.2.2.1

Berdasarkan pada Gambar 4.11 yang terbentuk dari hasil perhitungan sesuai dengan Tabel 3.12, maka didapatkan atribut "HbA1c" sebagai node 1.1.2.2.1 dan semua value pada atribut "HbA1c" sudah memiliki label atau telah diketahui kelas nya untuk "HbA1c = Baik" memiliki kelas "Menuju Positif", "HbA1c = Sedang" memiliki kelas "Menuju Positif" dan untuk "HbA1c = Buruk" memiliki kelas "Positif".

\subsection{Mencari Node 1.1.3}

Untuk menentukan node 1.1.3 dilakukan perhitungan ulang dengan filter data untuk "GDS = Buruk" dan "Usia = Manula". Untuk mencari node 1.1.3 dapat dilakukan dengan menghitung atribut lain yang memiliki atribut "GDS=Buruk" dan "Usia = Manula".

Tabel 3.13 Mencari Node 1.1.3

\begin{tabular}{cccccccc}
\hline Atribut & Value & $\begin{array}{c}\text { Jumlah } \\
\text { Kasus } \\
(\mathrm{S})\end{array}$ & $\begin{array}{c}\text { Positif } \\
\text { (S1) }\end{array}$ & $\begin{array}{c}\text { Menuju } \\
\text { Positif } \\
\text { (S2) }\end{array}$ & $\begin{array}{c}\text { Negatif } \\
\text { (S3) }\end{array}$ & Entropy & Gain \\
\hline $\begin{array}{c}\text { GDS = Buruk } \\
\begin{array}{c}\text { NND Usia }= \\
\text { Manula }\end{array}\end{array}$ & 17 & 9 & 8 & 0 & 0,9975 & \\
\hline Jenis Kelamin & & & & & & & 1,6457 \\
\hline & Pria & 5 & 5 & 0 & 0 & 0 & \\
\hline & Wanita & 12 & 4 & 8 & 0 & 0,9183 & \\
\hline GDP & & & & & & & 1,5159 \\
\hline & Baik & 1 & 0 & 1 & 0 & 0 & \\
\hline & Sedang & 10 & 3 & 7 & 0 & 0,8813 & \\
\hline Buruk & 6 & 6 & 0 & 0 & 0 & \\
\hline HbA1c & & & & & & & 1,2639 \\
\hline & Baik & 0 & 0 & 0 & 0 & 0 & \\
\hline & Sedang & 9 & 1 & 8 & 0 & 0,5033 & \\
\hline Buruk & 8 & 8 & 0 & 0 & 0 & \\
\hline
\end{tabular}

Berdasarkan perhitungan pada tabel 3.13, dapat diketahui bahwa nilai gain terbesar adalah atribut "Jenis Kelamin" yaitu sebesar 1,6457. Sehingga atribut "Jenis Kelamin" menjadi node selanjutnya yaitu node 1.1.3. dan terdapat 2 nilai atribut, yaitu Pria dan Wanita.

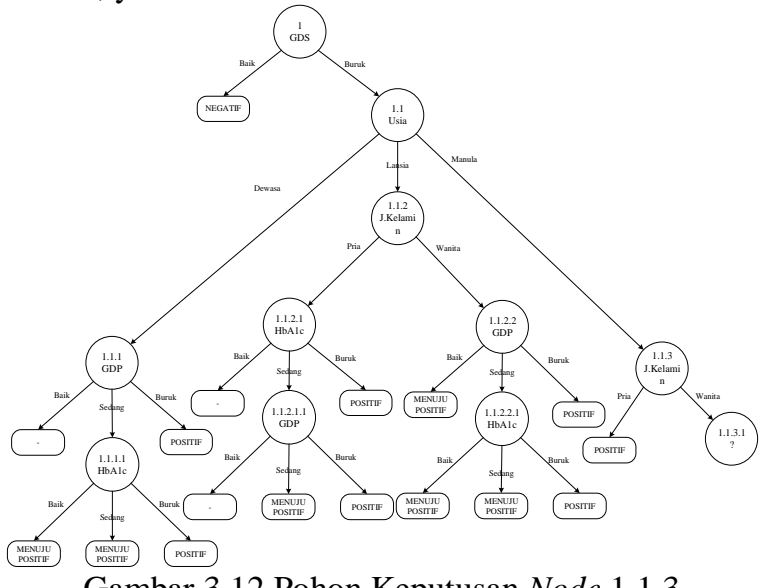

Gambar 3.12 Pohon Keputusan Node 1.1.3

Berdasarkan pada Gambar 3.12 yang terbentuk dari hasil perhitungan sesuai dengan Tabel 3.13, maka didapatkan atribut "Jenis Kelamin" sebagai node 1.1.3. Dapat dilihat bahwa untuk nilai atribut "Jenis Kelamin = Pria" telah memiliki label yaitu "Positif" sedangkan untuk nilai atribut "Jenis Kelamin=Wanita" masih tanda tanya artinya masih memiliki nilai atau masih ragu-ragu dalam mendiagnosa apakah dikatakan "Positif", "Menuju Positif" atau "Negatif" maka diperlukan perhitungan ulang untuk "GDS=Buruk", "Usia=Manula", "Jenis Kelamin=Wanita" dan akan menjadi node selanjutnya yaitu node 1.1.3.1.

\subsection{Mencari Node 1.1.3.1}

Untuk menentukan node 1.1.3.1 maka dilakukan perhitungan ulang dengan mencari atribut lain yang bernilai "GDS = Buruk", "Usia = Manula" dan "Jenis Kelamin = Wanita" karena untuk "Jenis Kelamin = Pria" telah diketahui kelasnya atau telah ditentukan leaf node nya yaitu "Positif". 
Tabel 3.14 Mencari Node 1.1.3.1

\begin{tabular}{llllllll}
\hline Atribut & Value & $\begin{array}{c}\text { Jumlah } \\
\text { Kasus } \\
\text { (S) }\end{array}$ & $\begin{array}{c}\text { Positif } \\
\text { (S1) }\end{array}$ & $\begin{array}{c}\text { Menuju } \\
\text { Positif } \\
\text { (S2) }\end{array}$ & $\begin{array}{c}\text { Negatif } \\
\text { (S3) }\end{array}$ & Entropy & Gain \\
\hline $\begin{array}{c}\text { GDS = Buruk } \\
\text { AND Usia }=\end{array}$ & & & & & & & \\
$\begin{array}{c}\text { Manula AND } \\
\text { J.Kelamin }= \\
\text { Wanita }\end{array}$ & 12 & 4 & 8 & 0 & 0,9183 & \\
\hline GDP & & & & & & & \\
\hline & Baik & 1 & 0 & 1 & 0 & 0 & \\
\hline & Sedang & 8 & 1 & 7 & 0 & 0,5436 & \\
\hline & Buruk & 3 & 3 & 0 & 0 & 0 & \\
\hline HbAlc & & & & & & & 1,2957 \\
\hline & Baik & 0 & 0 & 0 & 0 & 0 & \\
\hline & Sedang & 9 & 1 & 8 & 0 & 0,5033 & \\
\hline Buruk & 3 & 3 & 0 & 0 & 0 & \\
\hline
\end{tabular}

Berdasarkan perhitungan pada tabel 3.14, dapat diketahui bahwa nilai gain terbesar adalah atribut "HbA1c" yaitu sebesar 1,2957. Sehingga atribut "HbA1c" menjadi node selanjutnya yaitu node 1.1.3.1 dan terdapat 3 nilai atribut yaitu Baik, Sedang dan Buruk.

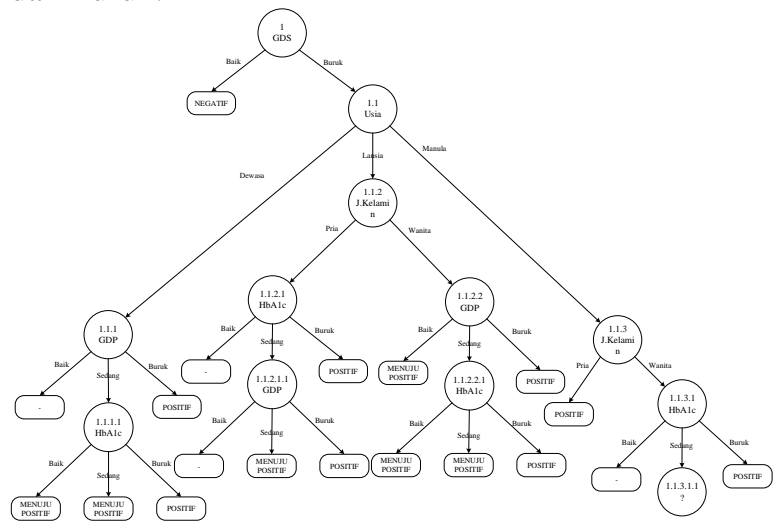

Gambar 3.13 Pohon Keputusan Node 1.1.3.1

Berdasarkan pada Gambar 3.13 yang terbentuk dari hasil perhitungan sesuai dengan Tabel 3.14, maka didapatkan atribut "HbA1c" sebagai node 1.1.3.1. Dapat dilihat bahwa untuk nilai atribut "HbAlc = Baik" telah memiliki label yaitu "_" artinya tidak ada data yang ditunjukkan pada kondisi tersebut dan untuk nilai atribut "HbAlc = Buruk" juga telah memiliki label yaitu "Positif" sedangkan untuk nilai atribut "HbAlc = Sedang" masih tanda tanya artinya masih memiliki nilai atau masih raguragu dalam mendiagnosa apakah dikatakan "Positif", "Menuju Positif" atau "Negatif" maka diperlukan perhitungan ulang untuk "GDS = Buruk", "Usia = Manula", "Jenis Kelamin = Wanita", "HbA1c = Sedang" dan akan menjadi node selanjutnya yaitu node 1.1.3.1.1.

\subsection{Mencari Node 1.1.3.1.1}

Untuk menentukan node 1.1.3.1.1 maka dilakukan perhitungan ulang dengan mencari atribut lain yang bernilai "GDS = Buruk", "Usia = Manula", "Jenis Kelamin = Wanita" dan "HbA1c = Sedang" karena untuk "HbA1c = Baik" dan "HbA1c = Buruk" telah diketahui label atau leaf node nya.
Tabel 3.15 Mencari Node 1.1.3.1.1

\begin{tabular}{|c|c|c|c|c|c|c|c|}
\hline Atribut & Value & $\begin{array}{c}\text { Jumlah } \\
\text { Kasus } \\
\text { (S) }\end{array}$ & $\begin{array}{l}\text { Positif } \\
\text { (S1) }\end{array}$ & $\begin{array}{c}\text { Menuju } \\
\text { Positif } \\
\text { (S2) }\end{array}$ & $\begin{array}{l}\text { Negatif } \\
\text { (S3) }\end{array}$ & Entropy & Gain \\
\hline \multirow[t]{5}{*}{$\begin{array}{c}\text { GDS }=\text { Buruk AND Usia }= \\
\text { Manula AND J.Kelamin }= \\
\text { Wanita AND HbAlc }= \\
\text { Sedang }\end{array}$} & & 9 & 1 & 8 & 0 & 0,5033 & \\
\hline & & & & & & & 0,5033 \\
\hline & Baik & 1 & 0 & 1 & 0 & 0 & \\
\hline & Sedang & 7 & 0 & 7 & 0 & 0 & \\
\hline & Buruk & 1 & 1 & 0 & 0 & 0 & \\
\hline
\end{tabular}

Berdasarkan pada tabel 3.15, dapat diketahui bahwa nilai gain terbesar adalah atribut "GDP" yaitu sebesar 0,5033. Sehingga atribut "GDP" terpilih menjadi node selanjutnya yaitu node 1.1.3.1.1 dan terdapat 3 nilai atribut, yaitu Baik, Sedang dan Buruk.

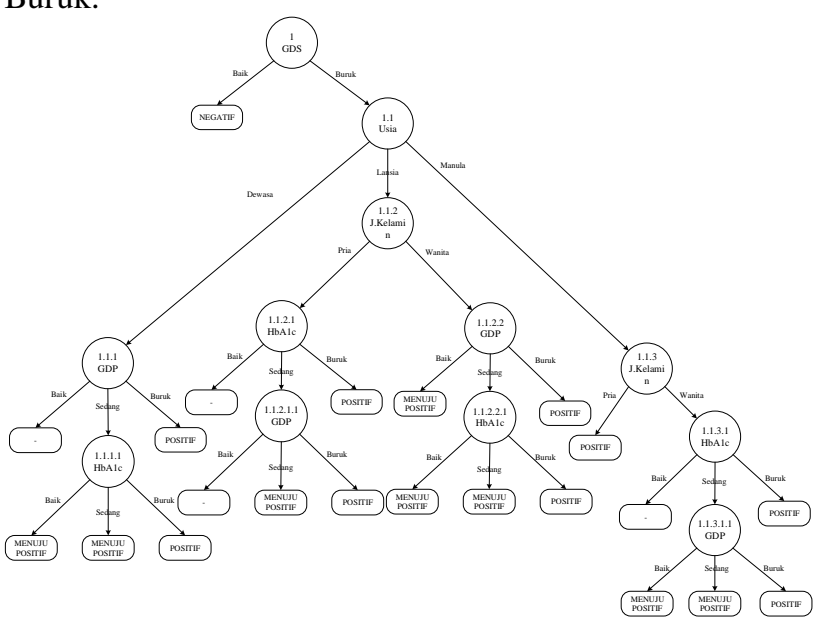

Gambar 3.14 Pohon Keputusan Node 1.1.3.1.1

Berdasarkan pada Gambar 3.14 yang terbentuk dari hasil perhitungan sesuai dengan Tabel 3.15, maka didapatkan atribut "GDP" sebagai node 1.1.3.1.1. Dapat dilihat pada semua nilai atribut "GDP" bahwa semua kasus pada cabang telah memiliki label. Dengan demikian decision tree atau pohon keputusan telah selesai dihitung dan artinya sudah tidak memiliki output. Maka hasil dalam decision tree atau pohon keputusan dapat menghasilkan rule menggunakan kaidah IF-THENELSE.

Berikut adalah rule/aturan yang terbentuk dari pohon keputusan yang dapat dilihat pada Tabel 3.16. 
Najib, dkk. Klasifikasi Diagnosa Penyakit Diabetes Mellitus (DM)

Menggunakan Algoritma C4.4

Tabel 3.16 Aturan Pohon Keputusan

\begin{tabular}{|c|c|}
\hline NO & RULE / ATURAN \\
\hline \multirow{2}{*}{ R1 } & IF GDS = "Baik" \\
\hline & THEN Diabetes = "NEGATIF" \\
\hline \multirow{2}{*}{$\mathrm{R} 2$} & IF GDS = "Buruk" AND Usia = "Dewasa" AND GDP = "Buruk" \\
\hline & THEN Diabetes = "POSITIF" \\
\hline \multirow{2}{*}{ R3 } & IF GDS = "Buruk" AND Usia = "Dewasa" AND GDP = "Sedang" AND HbAlc = "Baik" \\
\hline & THEN Diabetes = "MENUJU POSITIF" \\
\hline \multirow{2}{*}{$\mathrm{R} 4$} & IF GDS = "Buruk" AND Usia = "Dewasa" AND GDP = "Sedang" AND HbAlc = "Sedang" \\
\hline & THEN Diabetes = "MENUJU POSITIF" \\
\hline \multirow{2}{*}{ R5 } & IF GDS = "Buruk" AND Usia = "Dewasa" AND GDP = "Sedang" AND HbAlc = "Buruk" \\
\hline & THEN Diabetes = "POSITIF" \\
\hline \multirow{2}{*}{ R6 } & $\begin{array}{l}\text { IF GDS = "Buruk" AND Usia = "Lansia" AND Jenis Kelamin = "Pria" AND HbAlc = } \\
\text { "Buruk" }\end{array}$ \\
\hline & THEN Diabetes = "POSITIF" \\
\hline \multirow{2}{*}{$\mathrm{R} 7$} & $\begin{array}{l}\text { IF GDS = "Buruk" AND Usia = "Lansia" AND Jenis Kelamin = "Pria" AND HbAlc = } \\
\text { "Sedang" AND GDP = "Sedang" }\end{array}$ \\
\hline & THEN Diabetes = "MENUJU POSITIF" \\
\hline \multirow[t]{2}{*}{ R8 } & $\begin{array}{l}\text { IF GDS = "Buruk" AND Usia = "Lansia" AND Jenis Kelamin = "Pria" AND HbAlc = } \\
\text { "Sedang" AND GDP = "Buruk" }\end{array}$ \\
\hline & THEN Diabetes = "POSITIF" \\
\hline \multirow[t]{2}{*}{ R9 } & $\begin{array}{l}\text { IF GDS = "Buruk" AND Usia = "Lansia" AND Jenis Kelamin = "Wanita" AND GDP = } \\
\text { "Baik" }\end{array}$ \\
\hline & THEN Diabetes = "MENUJU POSITIF" \\
\hline \multirow[t]{2}{*}{ R10 } & $\begin{array}{l}\text { IF GDS = "Buruk" AND Usia = "Lansia" AND Jenis Kelamin = "Wanita" AND GDP = } \\
\text { "Buruk" }\end{array}$ \\
\hline & THEN Diabetes = "POSITIF" \\
\hline …...... & (2) \\
\hline \multirow[t]{2}{*}{ R18 } & $\begin{array}{l}\text { IF GDS = "Buruk" AND Usia = "Manula" AND Jenis Kelamin = "Wanita" AND HbAlc = } \\
\text { "Sedang" AND GDP = "Buruk" }\end{array}$ \\
\hline & THEN Diabetes = "POSITIF" \\
\hline
\end{tabular}

\subsection{Menghitung Akurasi}

Pada tahap ini dilakukan perhitungan untuk melihat akurasi yang dihasilkan dengan menggunakan confussion matrix untuk mengetahui seberapa besar error yang terjadi pada data penelitian ini. Data prediksi menggunakan Algoritma C4.5 dapat dilihat pada Tabel 3.17.

Tabel 3.17 Hasil Perbandingan

\begin{tabular}{cccccccc}
\hline No & $\begin{array}{c}\text { Jenis } \\
\text { Kelamin }\end{array}$ & Usia & GDP & GDS & HbAlc & Diabetes & $\begin{array}{c}\text { Prediksi } \\
\text { Error } \\
\text { C4.5 }\end{array}$ \\
\hline 1 & WANITA & LANSIA & BURUK & BURUK & BURUK & POSITIF & POSITIF \\
\hline 2 & PRIA & DEWASA & SEDANG & BURUK & SEDANG & $\begin{array}{c}\text { MENUJU } \\
\text { POSITIF }\end{array}$ & $\begin{array}{c}\text { MENUJU } \\
\text { POSITIF }\end{array}$ \\
\hline 3 & WANITA & LANSIA & BURUK & BURUK & BURUK & POSITIF & POSITIF \\
4 & PRIA & DEWASA & BAIK & BAIK & BAIK & NEGATIF & NEGATIF \\
\hline 5 & WANITA & LANSIA & SEDANG & BURUK & BURUK & POSITIF & POSITIF \\
\hline 6 & WANITA & DEWASA & BAIK & BAIK & BAIK & NEGATIF & NEGATIF \\
\hline 7 & PRIA & LANSIA & BAIK & BAIK & BAIK & NEGATIF & NEGATIF \\
\hline 8 & WANITA & MANULA & SEDANG & BURUK & SEDANG & $\begin{array}{c}\text { MENUJU } \\
\text { POSITIF }\end{array}$ & $\begin{array}{c}\text { MENUJU } \\
\text { POSITIF }\end{array}$ \\
\hline 9 & WANITA & LANSIA & SEDANG & BURUK & SEDANG & $\begin{array}{c}\text { MENUJU } \\
\text { POSITIF }\end{array}$ & $\begin{array}{c}\text { MENUJU } \\
\text { POSITIF }\end{array}$ \\
\hline 10 & WANITA & DEWASA & BURUK & BURUK & BURUK & POSITIF & POSITIF \\
\hline$\ldots \ldots$ & $\ldots \ldots \ldots \ldots .$. & $\ldots \ldots \ldots \ldots .$. & $\ldots \ldots \ldots \ldots$ & $\ldots \ldots \ldots \ldots$ & $\ldots \ldots \ldots \ldots$ & $\ldots \ldots \ldots \ldots .$. & $\ldots \ldots \ldots \ldots . .$. \\
\hline 50 & PRIA & LANSIA & SEDANG & BURUK & SEDANG & $\begin{array}{c}\text { MENUJU } \\
\text { POSITIF }\end{array}$ & $\begin{array}{c}\text { MENUJU } \\
\text { POSITIF }\end{array}$ \\
\hline
\end{tabular}

Berdasarkan pada Tabel 3.17 dari jumlah kasus 50 yang telah dihitung menggunakan Algoritma C4.5 menghasilkan tidak ada data mengalami error $=0$. Tabel confussion matrix dan nilai akurasi yang dihitung dengan menggunakan persamaan 2.3 dan mempunyai hasil sebagai berikut.
Tabel 3.18 Perhitungan dengan Confusion Matrix

\begin{tabular}{c|ccc}
\hline \hline & \multicolumn{3}{|c}{ Actual Class } \\
\hline Kelas Prediksi $\downarrow$ & Positif & Negatif & Menuju Positif \\
\hline Positif & 22 & 0 & 0 \\
Negatif & 0 & 11 & 0 \\
Menuju Positif & 0 & 0 & 17 \\
\hline \hline
\end{tabular}

Berdasarkan pada tabel 3.18 diketahui kelas TP(True Positif) memiliki 22 data, kelas TN(True Negatif) memiliki 11 data, dan TMP(True Menuju Positif) memiliki 17 data. Sedangkan kelas FP(False Positif) memiliki 0 data, kelas FN(False Negatif) memiliki 0 data dan kelas FMP(False Menuju Positif) memiliki 0 data, jadi kesimpulan nya adalah dari tabel confussion matrix menghasilkan akurasi sebanyak $100 \%$.

\subsection{Pengujian Menggunakan Weka}

Pengujian pohon keputusan menggunakan aplikasi WEKA, data yang dipakai merupakan data hasil klasifikasi yang terdapat pada Tabel 3.18 dan data telah dirubah kedalam file bentuk format .csv. Hasil decision tree atau pohon keputusan dapat dilihat sebagai berikut.

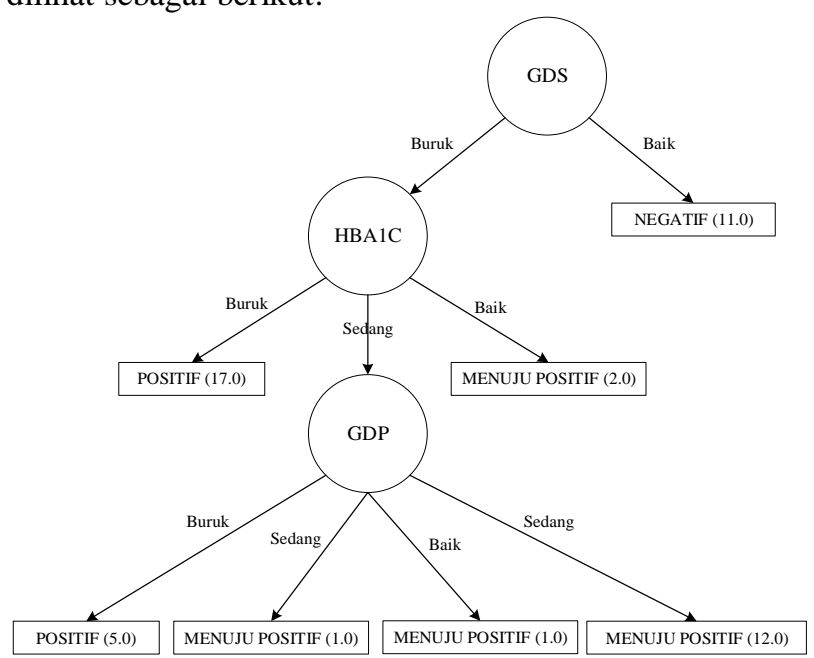

Gambar 3.15 Pohon Keputusan dengan WEKA

Berdasarkan pada hasil pohon keputusan menggunakan WEKA, dapat terlihat bahwa terdapat perbedaan dibandingkan pohon keputusan akhir yang ditunjukkan pada Gambar 3.15, hanya memiliki sedikit kesamaan yaitu pada root node. Pohon keputusan menggunakan WEKA menghasilkan rule yaitu jika atribut "GDS = Baik" maka hasil diagnosa diabetes nya adalah NEGATIF. Jika "GDS = Buruk" dan "HbAlc = Baik" hasil diagnosa diabetes nya adalah MENUJU POSITIF. Jika "GDS = Buruk" dan "HbAlc = Buruk" maka hasil diagnosa diabetes nya adalah POSITIF. Jika "HbA1c = Baik" dan "GDP = Buruk" maka diagnosa diabetesnya adalah POSITIF. Jika "GDS = Buruk", "HbA1c = Sedang" dan "GDP = Baik" maka diagnosa diabetes nya MENUJU POSITIF. Jika "GDS = Buruk", "HbA1c = Sedang" 
dan "GDP = Sedang" maka diagnosa diabetes nya MENUJU POSITIF. Jika "GDS = Buruk", "HbA1c = Sedang" dan "GDP = Buruk" maka diagnosa diabetes nya POSITIF.

\section{KESIMPULAN}

Adapun kesimpulan-kesimpulan yang didapatkan dalam penulisan ini:

1. Teknik klasifikasi menggunakan algoritma C4.5 dapat membantu mengklasifikasikan data diagnosa penyakit Diabetes Mellitus (DM).

2. Pohon keputusan yang dibuat dari hasil perhitungan manual menggunakan Microsoft Excel terdapat perbedaan yang cukup berbeda dibandingkan pohon keputusan akhir menggunakan $W E K A$ hanya ada sedikit kesamaan pada root node.

3. Hasil prediksi error pada data yang telah diklasifikasikan bernilai akurasi $100 \%$ artinya menurut perhitungan yang dilakukan menggunakan algoritma C4.5 tidak ada satupun error yang terjadi pada dataset, dapat disimpulkan bahwa algoritma C4.5 memiliki akurasi yang sangat tinggi pada perhitungan nya.

\section{DAFTAR PUSTAKA}

[1] I. Menarianti, "KLASIFIKASI DATA MINING DALAM MENENTUKAN PEMBERIAN KREDIT BAGI NASABAH KOPERASI," Ilm. Teknosains, vol. 1, no. 1, pp. 36-45, 2015.

[2] Rismayanti, "IMPLEMENTASI ALGORITMA C4.5 UNTUK MENENTUKAN PENERIMA BEASISWA DI STT HARAPAN MEDAN," Media Infotama, vol. 12, no. 2, pp. 116120, 2016.

[3] Sunjana, "Klasifikasi Data Nasabah Sebuah Asuransi Menggunakan Algoritma C4.5," Semin. Nas. Apl. Teknol. Inf. 2010, vol. 2010, no. Snati, p. D-31-D-34, 2010.

[4] Y. A. Fiandra, S. Defit, and Yuhandri, "Penerapan Alogoritma C4.5 untuk Klasifikasi Data Rekam Medis berdasarkan International Classification Diseases (ICD-10)," Rekayasa Sist. dan Teknol. Inf., vol. 1, no. 2, pp. 82-89, 2017.

[5] I. Novandya, Adhika., Oktria, "Penerapan Algoritma Klasifikasi Data Mining C4.5 Pada Dataset Cuaca Wilayah Bekasi," J. Format, vol. 6, no. 2, pp. 98-106, 2017.

[6] B. Sugara, D. Widyatmoko, B. S. Prakoso, and D. M. Saputro, "Penerapan Algoritma C4.5 untuk Deteksi Dini Autisme Pada Anak," Semin. Nas.
Teknol. Inf. dan Komun., vol. 2018, no. Sentika, pp. 87-96, 2018.

[7] D. T. Larose, Discovering Knowledge in Data: An Introduction to Data Mining. New Jersey: John Wiley \& Sons, 2005.

[8] M. Yuli, "Data Mining: Klasifikasi Menggunakan Algoritma C4.5," J. Edik Inform., vol. 2, no. 2, pp. 213-219, 2017.

[9] S. L. B. Ginting, W. Zarman, and I. Hamidah, "Prosiding Seminar Nasional Aplikasi Sains \& Teknologi (SNAST) 2014 Yogyakarta, 15 November 2014 ISSN: 1979-911X," Snast, vol. 3, no. November, pp. 211-216, 2014.

[10] S. Haryati, A. Sudarsono, and E. Suryana, "Implementasi Data Mining untuk Memprediksi Masa Studi Mahasiswa Menggunakan Algoritma C4.5," J. Media Infotama, vol. 11, no. 2, pp. 130$138,2015$.

[11] R. H. Pambudi and B. D. Setiawan, "Penerapan Algoritma C4 . 5 Untuk Memprediksi Nilai Kelulusan Siswa Sekolah Menengah Berdasarkan Faktor Eksternal," J. Pengemb. Teknol. Inf. dan Ilmu Komput., vol. 2, no. 7, pp. 2637-2643, 2018.

[12] F. F. Harryanto and S. Hansun, "Penerapan Algoritma C4.5 untuk Memprediksi Penerimaan Calon Pegawai Baru di PT WISE," Jatisi, vol. 3, no. 2, pp. 95-103, 2017.

[13] R. K. Amin, Indwiarti, and Y. Sibaroni, "Implementasi Klasifikasi Decision Tree Dengan Algoritma C4.5 Dalam Pengambilan Keputusan Permohonan Kredit Oleh Debitur," vol. 2, no. 1, pp. 1768-1778, 2015.

[14] Y. A. Rahman, Suparti, and Sugito, "Ketepatan Klasifikasi Status Pemberian Air Susu Ibu ( ASI ) Menggunakan Multivariate Adaptive Regression Splines ( MARS ) dan,” vol. 5, pp. 229238, 2016.

[15] R. A. Nugroho, Tarno, and A. Prahutama, "Klasifikasi Pasien Diabetes Mellitus Menggunakan Metode Smooth Support Vector Machine (Ssvm)," Gaussian, vol. 6, pp. 439-448, 2017.

[16] P. G. S. C. Nugraha, I. W. Aribawa., I. P. O. Priyana and G. Indrawan, "Penerapan Metode Decision Tree(Data Mining) Untuk Memprediksi Tingkat Kelulusan Siswa SMPN 1 Kintamani,". SEMNASVOKTEK, ISSN Online: 2541-3058, pp. 3544, 2016. 
Najib, dkk. Klasifikasi Diagnosa Penyakit Diabetes Mellitus (DM)

Menggunakan Algoritma C4.4 